\title{
Crop insurance with state support: ensuring the sustainability and competitiveness of the agricultural sector of the Volgograd region
}

\author{
Agnessa Inshakova \\ Volgograd State University, \\ Institute of Law, \\ Head of the department of civil and international \\ particular law. Volgograd, Russia \\ gimchp@ volsu.ru, ainshakova@ list.ru
}

\author{
Alexander Goncharov \\ Volgograd State University, \\ Institute of Law, \\ Professor of the department of civil and international \\ particular law. Volgograd, Russia \\ gimchp@volsu.ru, goncharova.sofia@gmail.com
}

\author{
Tatyana Deryugina \\ Volgograd Humanitarian Institute, \\ Pro-Rector for Research \\ Volgograd, Russia \\ rektor@vggi.ru
}

\begin{abstract}
The article is devoted to the problems of legal regulation of crop insurance. It is argued that this type of contract is an effective legal and economic mechanism that positively affects the sustainable development and competitiveness of the country as a whole, and of a particular region in the agricultural sector. The author studies the legal nature of the studied contractual structure, reveals the concept of the contract of crop insurance as an independent subspecies of property insurance. In the process of developing recommendations for improving legislation in the field of agricultural insurance, external factors for the agricultural sector, as well as climatic and other risks of a particular region are investigated. The conclusion is justified by the preference of the civil design of the insurance contract of agricultural crops with state support for other types of agricultural insurance is substantiated. As a result, it is recommended to eliminate the uncertainty of the place of the contract of agricultural insurance in the Russian legal system and civil law.
\end{abstract}

Keywords - insurance, agricultural insurance, a contract of crop insurance of agricultural crops with state support, civil contract, insurance on commercial terms, life insurance, insurance risks, insurance coverage, insurance products, the region's farmers

\section{INTRODUCTION}

In the conditions of modern intensive economic relations, a large number of economic operations insurance acts as an institution that provides monetary coverage due to the fact of property damage, it is a kind of shield that protects entrepreneurs from mistakes and unforeseen situations, contributes to the stability of business in a different areas.

The economic basis of the insurance, allowing him to perform the primary function, based on the special cash fund, which pays to entities risk events of which really happen. If every single entity accumulated such a monetary fund in its private finances and kept the necessary amounts in reserves, it would completely lose the working capital and simply would not be able to conduct business. Since the second half of the XX century, centralized insurance funds have been actively formed in the advanced states; they are filled on a reciprocal basis with budgetary allocations and contributions of economic entities - insurers. Such centralized funds have become the most widespread in the agricultural sector- sphere of entrepreneurship with high and diverse risks.

We consider agricultural risk to particularly difficult ones. From objective positions, this risk is characterized by an inaccurately predicted distribution in time, manifested by an alternation of poor harvest years and has a cumulative character. From subjective positions, the risk reflects the low level of professional training of rural producers, their weak adaptability to the economic environment, which is in assessing agricultural risk is difficult to formalize and assess in monetary terms. The state supports national rural producers by encouraging them to enter into crop insurance contracts; insurers pay them insurance indemnities in real-life risk cases. The insurer (insurance company) can successfully conduct their business in terms, when receipts from policyholders are significantly higher than the payments on risky cases. Therefore, system failures of insurers are possible in globally bad harvest years, which makes the state financial support of insurance in the agricultural sector even more important.

\section{MATERIALS AND METHODS}

Scientific article is prepared on the basis of normative documents and doctrinal developments of domestic scientists 
research. The international legal act, the Marrakesh agreement establishing the World Trade Organization, was used. In the the Russian legal base, the authors attention was focused on federal laws, including: the law of the RSFSR of 01.07.1970 "on approval of the Land Code of the RSFSR", the law of the Russian Federation of 27.11.1992 № 4015-1 "on the organization of Insurance Business in the Russian Federation", the Federal law of 25.07.2011 №260-FL "On State Support in the Field of Agricultural Insurance and Amendments to the Federal law "On the development of Agriculture". Also a subordinate normative acts: The Resolution of Administration of the Volgograd region from 25.01.2016 № 10-p "On granting of subsidies for compensation of part of expenses of agricultural producers for payment of insurance premiums accrued under the contracts of agricultural insurance in the Field of Crop and Livestock production", the Order of the Ministry of Agriculture of the Russian Federation from 29.12.2010 No. 455 "On the forms of documents for granting subsidies for compensation of part of expenses on insurance of crop, harvest of perennial plantings and planting of perennial plants and monitoring the effectiveness of their use", the Order of the Ministry of Agriculture of the Russian Federation from 10.04.2015 №133 "On approval of methodology for determining insurable value and size of loss (destruction) of agricultural crops harvest and planting of perennial plants and methods for determining insurable value and size of loss (death) of agricultural animals", the Order of the Ministry of Agriculture of the Russian Federation from 29.07.2016 No. 341 "On approval of the Plan of agricultural insurance by 2017" was used.

Scientific positions of Russian researchers on monographic literature, dissertations, periodicals and publications, including those, which included in the international citation bases, were studied.

The methodological basis of the article is the universal method of research - dialectical materialism. The authors used general scientific methods: analysis, synthesis, induction, comparison, analogy, abstraction. Among the particular scientific methods used: mathematical, comparative legal, formal legal methods.

\section{RESULTS AND DISCUSSION}

\section{A. Agricultural Insurance as a subspecies of property insurance}

The existing problems in the Russian legal system as a whole, affect the insurance of risks of subjects of agrarian sector sphere. The process of the Russian legislation updating on agricultural insurance is accompanied by changes due to the ratification of new international acts by the Russian Federation [1]. Numerous international agreements limits the contractual practice of agricultural insurance with state support, which posess the domestic producer of agricultural products in a formidible chakllange and does not contribute to its competitiveness improving [2].

Many laws, the content of which was filled with the concepts of Soviet law [3], have lost their force, normative legal acts, the novelties of which reflect the needs of modern social development was adopted [4]. However, until now, the place of the insurance contract in the system of civil law regulation has not been clearly defined, there is no statutory concept of the insurance contract, as well as its characteristics.

The domestic legal doctrine, as well as the legislator, demonstrates ambiguous approaches to the interpretations of the concepts and categories of insurance [5]. There is no unity in the security nature of the insurance contract and the procedures for its execution understanding. The issue of the functionality remains debatable, as regards the existing grounds for ensuring the fulfillment of obligations remains contentious, because there is no collateral property as the main feature of these legal relations [6]. The Institute of agricultural insurance for the legislation in the Russian Federation is new, so, there is therefore the incompleteness of its regulatory framework [7].

In our opinion, crop insurance of agricultural crops should be defined as the monetary reservation of funds to cover the property losses of the policyholder (beneficiary) due to the event of agricultural risk. Which is expressed in the reduction of the actual size of the harvest of agricultural crops, compared with the planned amount determined by the law and (or) contract. We believe that it is quite acceptable to use the term "agricultural insurance" as an identical term defined above. As part of the civil law insurance institute crop insurance is a subspecies of property insurance.

Crop insurance can be carried out within the framework of various programs offered by insurance companies in various ways to cover insurance risks. It can be insurance on commercial terms, a specialized program of insurance of greenhouse products, and, of course, insurance with state support. Russian legal theory has always assumed that the insurance contract served as the legal basis for the agreement of the parties, one of which for a certain fee undertakes to pay the other party for the death of any physical object, if any, will occur within the agreed period from the action of a certain destructive force.

Production of agricultural products everywhere is accompanied by the impact of a number of adverse factors, so insurance in the agricultural sector is urgently needed state support. Such financial assistance should be provided by taking into account the current indicators of economic development of the agricultural sector, as well as climatic and other risks of a particular region [8]. Thus, the region of location along with the type of crop production affects the calculation of crop insurance cost. Payment of the accrued insurance premium under the agricultural crop insurance contract with state support is made in the prescribed proportion from the regional budget. In this regard, it is difficult to overestimate the legislative consolidation of the algorithm of state support providing to the agricultural policyholder, as well as the procedure for the conclusion and execution of the insurance contract not only at the federal but also at the regional level.

The agricultural insurance with state support is provided under "compensation of the cost of crop insurance crops, harvest of perennial plantings and planting of perennial plants" 
[9] and reduces costs to farmers for crop insurance (real insurance rate) on $50 \%$ or more. Therefore, the financial and economic nature of the state support is a monetary subsidy allocated within the budget legislation and under the contract with the recipient of this subsidy. The period of crop insurance with the state support program using - until the end of harvesting. The insurance amount is calculated on the basis of the value of the crop, the insured yield of a particular crop, the area, where insured crop was planted. When you insuring perennial plantings - it based on the planting area, planting density and cost. The insurance amount is set at a rate of $80 \%$ or more of the insured value of the crop, perennial plantings, and farm animals. Participation of the agrarian policyholder in the insurance of agricultural risk shall not exceed $40 \%$ of insurance amount of this agreement.

Legal component and economic relations of the parties in agricultural insurance are methodologically connected by criteria of correctness of scientific concepts and are realized in practical activity. The insured event is a private event - the fact of civil financial responsibility of the insurer due to the risk event, which is occurred beyond his and the insurers physical or legal person's control. This circumstance determines the performance of the contract in which the monetary coverage of losses occurs, in the amount in advance which was discibed inthis contract [10].

Crop insurance of agricultural crops is also predetermined by the nature of the subject of insurance and is made for the prevention and compensation of losses, which may be expressed in shortage and loss of harvest. Shortfall is a concept introduced to determine the damage in the case of partial loss of harvest, which is expressed in quantitative and qualitative difference between the actual harvest and the harvest, which was supposed to get [11]. The size of the shortage is determined during the examination, its procedures we assess as controversial and in need of further correction. The insurance case does not occur if they presented evidence that there had been deliberate actions that led to the losses. The insurance organization is paid compensation in case of seizure of the harvest by the state authorities and local selfgovernment [12].

The construction of the fulfillment of obligations within the existing legal model of agricultural insurance allows the insurance company to treat the fulfillment of duties with disdain, which contradicts the essence of insurance of agricultural risks. It is necessary to introduce new ways to secure obligations on the part of the insurer and policyholder interests protection. In fact, currently there is an imbalance in favor of insurance companies, which leads to distortion of the purpose of agricultural insurance.

Insurance with state support is effective if the economic interests of the policyholder, the insurer, and the state coincide from the conclusion of such a contract, compared with the situation when such a contract was not concluded. The economic interest of the insurer consists in the formation of funds from the contributions of insurers and the state, allowing to compensate the losses arising from individual insurers as a result of the occurrence of insurance events, to profit from the insurance business. The policyholder is interested in fact? That chosen insurance program has provided a source of funds to cover losses in the insurance case. The economic interest of the state is not to spend additional budgetary funds to eliminate the consequences of emergencies in the form of crop failures and/or adverse environmental and climatic events in agriculture.

\section{B. Problems of implementation of relations in agricultural insurance}

As we can see, insurance is carried out by farmers in order to strengthen the stability of their business by obtaining additional budget financing from subsidies allocated for agricultural insurance, but when an insured event occurs, there is no dependence between the amount of real damage suffered as a result of adverse events and the amount of insurance compensation. Problems in relations with insurance companies arises among insurers due to the fact that in most cases they do not comply with agrotechnical measures, there is practically no high scientific agricultural culture in Soviet times [13].

For calculation of the losses and the damage size, received by the producer of agricultural production, for the previous 5 years the average value is received from 1 hectare of estimated crops. Consequently, the damage is the difference in monetary terms between the size of the received crop (in tons) multiplied by the purchase price (in rubles) of this crop in the current year and the average yield (in tons) for 5 years multiplied by the same price. The insured event is considered to have occurred only if more than $50 \%$ of crops are lost or the entire crop is lost. The last circumstance relating to the temporary reporting was introduced after 2010. It provokes discussion, because ones are not satisfied with the time when a final assessment of the damage will be given, and the others its size, if the multiplication in the calculation of the above difference is spend on the purchase price in a prosperous year.

The legal novelty is the introduction of regulation of damage suffered from the death of the property of the agricultural producer, which is not the main means of production, but necessary for him for normal life. In this case the usual scheme of calculation of damage at insurance cases is applied, that is, the market price is deducted from carrying value, the costs incurred for elimination of negative influence on a thing and the shortcomings received in this process.

In order to the agrarian policyholder received compensation, usually in cash, it is necessary to respect the procedure of collecting documents and evidence to confirm the insured event. In case of noncompliance with this circumstance because the Russian civil process has a formal nature, agricultural producer may lose the right of monetary coverage of the damage. These rules are fixed in the subordinate normative act and are valid for all subjects of the Russian Federation. The procedures for obtaining and the amount of insurance payments are fixed in the laws and regulations of the regions. In particular, for the Volgograd region these rules are fixed in the decision of the Government of the subject. According to the Russian legislation, the amount of payments may not be lower than the established percentage of the insurance benefit. [14]. In the Volgograd 
region, this percentage is always equal to the Federal one, which is not correct, because it does not contribute to overcoming influence of adverse agroclimatic factors for the region, which, in turn, does not contribute to the development of crop insurance. The policyholder must provide documents within 30 working days after the date of formation of the register of recipients of insurance subsidies. The Committee of agriculture of the Volgograd region quarterly makes a request from insurance companies about the concluded contracts of agricultural insurance and payments.

As a separate benefit for the regional agricultural producer, a commodity-money subsidy was introduced. The mechanism is that the producer of agricultural products should to supply at the domestic market of the region a certain amount of its products, while from the budget to him, as the policyholder, the amount allocated to pay a part of the insurance premium to the insurer. At first, it is controversial that this is a clearly fixed volume of supplied products. It would be better to introduce a minimum and maximum number of products, because in agriculture it is difficult to accurately calculate the amount of harvest. Secondly, we view as harmful, non-market intervention of the state in the process of pricing for agricultural products, because in essence there is an individual purchase of its products from an agrarian, which distorts the legal basis of competition. In case of non-use of the specified subsidy, all sum or its balance returns to the regional budget. If the amount within a month has not been fully returned, the Executive authority has the right to file a grant to the recipient in court [15].

In the Volgograd region, as in other regions of the Russian Federation, insurance payments are made from the funds of a special Fund, where insurers deduct at least $5 \%$ of the insurance payments. The number of payments can be more, but not less than this amount. In the Volgograd region, the same 5\% enshrined in Federal law [16]. This regulation is hardly call correct or incorrect for the development of agricultural insurance in the region. On the one hand, it attracts insurance companies, on the other hand, the Fund may not be enough if events such as poor harvest of 2010 happens again.

In particular, unacceptable space is the fact that procedures of collection of additional funds from insurance companies in case of shortage of means of special Fund for insurance payments to farmers in regional legislation of the Volgograd region is not fixed. Therefore, if the Fund is insufficient, judicial procedures will be launched, and additional costs on the part of agricultural insurers, which in the end can lead them to financial insolvency, will occur. Formula of insurance payments in Volgograd region conforms to Federal law and in its calculation are deducted the average cost of harvesting that farmers did not suffer due to the fact that clean he had nothing. Non-received funds are determined in the same way as in the calculation procedure, based on the current cost of products for the calendar month following the submission of a package of documents on insurance payment for crop failure. As agreed by the parties, the insurer may pay no more than $35 \%$ of the estimated total insurance benefit - for current expenses for the next crop planting [15].
Due to the geographical position in the Volgograd region, there are a limited number of agro-climatic factors which distinguish the region from neighboring regions of the Russian Federation, these negative factors inhibit the development of the crop industry. However, Volgograd region occupies the 3rd place in cropland quantity, conceding only the Altai and the Orenburg. Unfortunately, having such resources, the Volgograd region takes only 10th place in terms of agricultural production and 13th place in terms of crop production.

\section{CONCLUSION}

In the Volgograd region, at the regional level, insufficient attention is paid to the development of legal measures to stimulate agricultural insurance. This leads to the fact that regional farmers losing at the stability of their farms, in the competitiveness to rural producers from other regions of the Russian Federation. An effective measure in this regard is the conclusion of agricultural crop insurance contracts with state support. In addition, attractiveness-stimulating measures to risk insurance activities attractiveness for regional farmers, to cumbersome and unjustified duration of procedures for obtaining subsidies for payment of insurance premiums to insurers elimination, to optimize the legal regulation of state support for agricultural insurance in general, are needed.

According to the Russian legislation, the contract of agricultural insurance should be attributed to the variety of insurance contracts and recognize it in the current regulation of a mixed unnamed contract. It contains elements of contracts of property insurance, insurance of entrepreneurial risk, as well as elements of Contracting (the subject of insurance is non - existent at the time of conclusion of the material world the future harvest). So, these qualities characterized the contract of agricultural insurance in the current civil law regulation, which entails a decrease in its effectiveness as a contractual structure and mechanism of legal support of sustainable and competitive agricultural sector of individual regions and the country as a whole.

We suggest that, for uncertainty elimination of the place of crop insurance contract in the Russian legal system and in civil law is necessary:

- at first, to change article 933 of the civil code of the Russian Federation, by providing the possibility of concluding an insurance contract for business risk in favor of a third party in cases, which determined by law;

- Secondly, to finish the operating legal regulation of subsidizing of agricultural insurance, in particular, provisions of the Federal Law from 25.07.2011 No. 260-FL. It is necessary to add in it the special regulations allowing authorized body of the subject of the Russian Federation to sign in agreements of agricultural insurance by its name in favor of the agricultural producers, which is located at the territory of such subject. These powers of the subject of the Russian Federation shall be feasible both in the personal order and in concerning the uncertain circle of agricultural producers. We proposed for all insurance companies located in the territory of the subject of the Russian Federation, the conclusion of the contract of agricultural insurance would be 
mandatory. In the interests of agricultural producers, the signed agreement between the authorized body and the insurance company shall extend its effect to a particular agricultural producer only after the introduction of the legally prescribed part of the insurance premium.

The practical implementation of the proposed recommendations allows to regulate more precise of complex relations on insurance between all parties (insurer, insured and beneficiary), and at the same time, to ensure the timeliness and completeness of insurance payments. Introduction of these adjustments to the legal regulation will allow:

- significantly reduce the amount of insurance premiums by more precise management of insurance risks and expanding the range of insurance products. Obviously, for example, on the territory of the Volgograd region, the probability of all crops and animal deaths from the earthquake is minimal, however, the risk of such death from natural fire the highest. Consequently, the authorized body in a particular region can more detail and accurately form a set of risks, which will be insured in this region;

- significantly increase the confidence of agricultural producers in the insurance of their property interests by significantly reducing the time for insurance payments. it is proposed to provide the possibility of direct payment of the insurance amount or a part of it to the agrarian insured by the authorized body, with regression to the insurance company, of course, within the existing legal restrictions.

\section{Acknowledgment}

The study was carried out within the framework of the RFFR grant (project № 17-03-00136 «Modernization of legal regulation of crop insurance, implemented with state support». Project leader: Inshakova A. O., artists: Uskov M. S. Kazachenok, O. P., Ryzhenkov A. Ya.).

\section{References}

[1] Marrakesh Agreement establishing the World Trade Organization (Marrakesh, April 15, 1994) (rev. and add., intro in force 27.11.2014) // ATP «Consultant Plus»).

[2] Anisimov A.P., Ryzhenkov A.Ja. The issue of the strengthening public role in making envi-ronmentally significant deci-sions at the international and national level, with special reference to Russian legislation // Acta Juridica Hungarica (Hungary). - 2014. - Vol. 55. - No. 1 (march). - PP. 71-86.

[3] See., for example, The law of RSFSR from 01.07.1970 «On approval of the Land Code of the RSFSR» ( with « Land Code of the RSFSR ») // Vedomosti SV RSFSR. 1970. № 28. Art. 581.

[4] The Law of the Russian Federation from 27.11.1992 № 4015-1 (as amended on 26.07.2017) «On organization of Insurance business in the Russian Federation» (as amended. and add., Intro. in force from 22.08.2017) / / Rossiyskaya Gazeta. 1993. No. 6; Federal Law No. 264FL of 29.12.2006 (ed.of 01.07.2017) «On the Development of Agriculture»// Collection of legislation of the Russian Federation. 2007.
No. 1 (1 h). St. 27; Federal Law from 25.07.2011 № 260-FL (ed. from 23.06.2016) «On the state support in sphere of agricultural insurance and on introducing amendments to the Federal law «About agriculture development»// collected legislation of the Russian Federation. 2011. No. 31. Art. 4700.

[5] Anisimov A.P., Kamyshansky V.P., Karnushin V.E. General theoretical concept of the contract: a glance from russian civil law // Law and Economics Yearly Review (United Kingdom). - 2016. - Volume 5. Part 2. - P. 353-377.

[6] Nosov V.V. Development stages of agricultural insurance with state support// Intelligence. Innovations. Investment. 2016. № 6. p. 5.

[7] Uskova M.S. To the Problem of the Legal Nature of Crop Insurance Contract// Legal Concept. 2016. № 3. C. 102.

[8] V. I. Gaiduk, V. Shevtsov, Kalitko S. A. Risk Management in agricultural business // Theory and practice of social development. 2013. №3. C. 177 .

[9] Order of the Ministry of Agriculture of the Russian Federation from 29.12.2010 №455 « On the forms of documents for the provision of subsidies to compensate for part of the costs of crop insurance, perennial plantings and planting perennial plantations and control over the effectiveness of their use» // Collection of legislation of the Russian Federation. 2010. No. 4. Art. 396.

[10] Bormotov A.V. Insurance of liability under the contract as a means of ensuring fulfillment of obligations // Bulletin of Perm University. Juridical sciences. - 2010. №3. p. 96.

[11] See: The order of the Ministry of Agriculture of the Russian Federation from 10.04.2015 №133 «On approval of the methodology for determining the insurance value and the amount of loss (death) of crops and planting perennial plantations and methods for determining the insurance value and the amount of loss (death) of farm animals» / / Collection of legislation. 2015. No. 5. St. 302; Davletyarova E. A., Plyuschikov V. G. and D. R. Modern methodology and methods of expert and technological support of crop insurance of agricultural crops: Proc. benefit. M.: PFUR, 2008. P. 68.

[12] Nikitin A. V. Crop Insurance with state support: scientific edition. Michurinsk: publishing house of Michurin. State. Agrar. un-ty, 2006. P. 80 .

[13] Kotar O. K. The Development of Agricultural insurance with state support in Russia in the conditions of globalization: diss ... kand. cand. econom. sciences. Saratov, 2014. p. 51.

[14] Order of the Ministry of Agriculture of the Russian Federation from 29.07.2016 No. 341 (ed. by 17.11.2016) "On approval of the Plan of agricultural insurance by 2017" // ATP "Consultant Plus".

[15] Resolution of Administration of the Volgograd region from 25.01.2016 No. 10-p « On providing subsidies for compensation of part of expenses of agricultural producers for payment of the insurance premium added under agreements of agricultural insurance in the field of plant growing and animal husbandry» (in the edition of the resolution of Administration of the Volgograd region from 08.08.2016 No. 422-p) // official site of the Volgograd region. - Access mode: http://www.volgograd.ru/ documents/npa.php?ELEMENT_ID=128147.I.

[16] Federal law No. 260-FL from 25.07.2011 (ed.of 23.06.2016) «On state support in the field of Agricultural insurance and on amendments to the Federal law on the development of Agriculture» / / Russian Federation legislative Assembly. 2011. No. 31. Art. 4700. 